Joanna ZYCH

Akademia Sztuki Wojennej ${ }^{1}$

Wydzial Bezpieczeństwa Narodowego

j.zych@akademia.mil.pl

ORCID 0000-0001-9187-8588

https://doi.org/10.34739/dsd.2019.02.02

\title{
ROLA BRONI NUKLEARNEJ W IZRAELSKIEJ STRATEGII ODSTRASZANIA MILITARNEGO
}

\begin{abstract}
ABSTRAKT: Celem artykułu jest wykazanie, jaką rolę w izraelskiej strategii odstraszania odgrywa broń nuklearna. Przyjęto założenie, że o potencjale odstraszania izraelskiego arsenału jądrowego decyduje celowe utrzymywanie go w tajemnicy (tzw. strategia amimut). Założono także, że odstraszanie nuklearne stanowi ważną część składową strategii odstraszania militarnego Izraela, ze względu na zmieniający się charakter zagrożeń nie jest jednak jej głównym elementem. W opracowaniu zastosowano teoretyczne metody badawcze: analizę krytyczną i analizę porównawczą źródeł, opracowań naukowych, dokumentów strategicznych oraz komunikatów przedstawicieli władz Izraela. Niniejszy artykuł stanowi próbę uchwycenia specyfiki strategii odstraszania nuklearnego Izraela i cech odróżniających ją od odstraszania innych państwa nuklearnych.
\end{abstract}

SŁOWA KLUCZOWE: broń nuklearna, odstraszanie, Izrael, Bliski Wschód

\section{THE ROLE OF NUCLEAR WEAPONS IN THE ISRAELI MILITARY DETERRENCE STRATEGY}

\begin{abstract}
ABSTRAKT:The aim of the article is to answer the question: What role does nuclear weapon play in Israeli strategy of deterrence? The main hypothesis of the paper is based on the assumption, that the deterrence potential of the Israeli nuclear arsenal is strictly determined by deliberate ambiguity (so-called amimut). The author also assumes that nuclear deterrence plays a significant role in the general Israeli deterrence strategy. However, due to the changing nature of threats, it is not its core element. The author used the following theoretical research methods: critical analysis and comparative analysis of sources, scientific studies, strategic documents as well as selected speeches of the Israeli authorities. This article can be seen as an attempt to capture the specifics of the Israeli nuclear deterrence strategy and the features that distinguish it from deterrence of other nuclear states.
\end{abstract}

KEYWORDS: nuclear weapons, deterrence, Israel, Middle East

\footnotetext{
${ }^{1}$ War Studies Academy; Poland.
} 


\section{WPROWADZENIE}

Rozwijany od lat 60. XX w. izraelski program nuklearny, mimo nacisków społeczności międzynarodowej, wciąż pozostaje nieobjęty kontrolą Międzynarodowej Agencji Atomowej (International Atomic Energy Agency - IAEA). Podawana do wiadomości publicznej liczebność posiadanych przez Izrael głowic nuklearnych opiera się wyłącznie na szacunkach. Choć zarówno sojusznicy, jak i potencjalni przeciwnicy Izraela zdają się przyjmować istnienie takiego potencjału za pewne, to same władze izraelskie nigdy nie potwierdziły ani nie zaprzeczyły, że ich państwo posiada broń jądrową ${ }^{2}$. Brak oficjalnego potwierdzenia istnienia tego typu broni nie przeszkadza Izraelowi w wykorzystywaniu jej jako elementu strategii odstraszania militarnego. W regionie Bliskiego Wschodu, gdzie do tej pory żadne inne państwo nie weszło $\mathrm{w}$ posiadanie broni jądrowej, samo prawdopodobieństwo dysponowania nią stanowi czynnik odstraszający innych aktorów państwowych przed podejmowaniem działań agresywnych.

Celem niniejszego artykułu jest wykazanie, jaką rolę w izraelskiej strategii odstraszania militarnego odgrywa broń nuklearna oraz jakie jest jej znaczenie w porównaniu z innymi elementami tej strategii. Mimo że sam temat broni jądrowej Izraela często opisywany jest w publikacjach naukowych na temat nieproliferacji broni masowego rażenia, większość z nich skupia się na braku międzynarodowej kontroli nad stanem i rozwojem izraelskiego arsenału jądrowego oraz na konsekwencjach tej sytuacji dla bezpieczeństwa w regionie ${ }^{3}$. Znaczenie broni jądrowej w izraelskiej koncepcji odstraszania często bywa wyolbrzymiane, zwłaszcza przez autorów przyjmujących założenie o niemal nieograniczonym potencjale odstraszania broni masowego rażenia i jej przewagi nad innymi czynnikami, warunkującymi skuteczne odstraszanie militarne ${ }^{4}$. Celem opracowania jest więc również weryfikacja, czy arsenał nuklearny faktycznie odgrywa wiodącą rolę we współczesnej izraelskiej strategii odstraszania.

Niniejszy artykuł stanowi próbę odpowiedzi na pytanie, w jaki sposób „,broń, której nikt nie widział", może zostać wykorzystana do celów odstraszania militarnego oraz jaką rolę w kształtowaniu strategii odstraszania Izraela odgrywa domniemane posiadanie broni nuklearnej. Za hipotezę roboczą przyjęto założenie, że o potencjale odstraszania izraelskiego arsenału jądrowego decyduje przede wszystkim celowe utrzymywanie go w tajemnicy. Założono także, że odstraszanie nuklearne stanowi część składową izraelskiej strategii odstraszania militarnego, nie jest jednak jej głównym elementem.

\footnotetext{
2 S. Kile, H. Kristensen, World nuclear forces [w:] SIPRI Yearbook 2018: Armaments, Disarmament and International Security, Stockholm 2018, s. 278.

${ }^{3}$ Np. S. Khan, Nuclear Proliferation Dynamics in Protracted Conflict Regions. A Comparative Study of South Asia and the Middle East, London 2003; A. Krepnievich, Critical Mass: Nuclear Proliferation in the Middle East, Washington 2013; B. Riedel, A. Dowty, Nuclear Proliferation: The Israeli Case, „International Studies Quarterly” 1978, Vol. 22 (1), s. 79-120; G. Samore, Report: Managing Nuclear Proliferation in the Middle East, Washington 2008.

${ }^{4}$ Np. L.R . Beres, Z. Shoval, Creating a Seamless Strategic Deterrent: an Israel Case Study, Modern War Institute, https://mwi.usma.edu/creating-seamless-strategic-deterrent-israel-case-study (18.10.2019). Vide: W. Farr, The Third Temple's holy of holies: Israel's nuclear weapons, Maxwell 1999, s. 18.
} 
W rozumieniu ogólnym strategia to,teoria i praktyka określająca sposoby myślenia i działania przedstawicieli najwyższych władz w danej dziedzinie, charakteryzujące się wysokim stopniem uogólnienia, dużym, horyzontem czasowym oraz umiejętnością pozyskiwania zasobów dla osiągnięcia założonych celów" " Ze względu na specyfikę analizowanego zagadnienia dla potrzeb niniejszego opracowania przyjęto jednak węższą definicję, odnoszącą się do strategii stricte militarnej. Pojawiający się w dalszych rozważaniach termin „strategia” odnosić się więc będzie do strategii wojskowej, rozumianej jako „element strategii bezpieczeństwa narodowego lub międzynarodowego, określający sposób, w jaki należy rozwijać i wykorzystywać potencjał militarny dla osiągnięcia celów państwa"6.

W opracowaniu zastosowano teoretyczne metody badawcze: analizę krytyczną i analizę porównawczą źródeł oraz opracowań naukowych (ze szczególnym uwzględnieniem opracowań wydawanych przez izraelskie ośrodki badawcze), a także analizę dokumentów strategicznych oraz wybranych komunikatów przedstawicieli władz Izraela.

\section{ROZWÓJ POTENCJAŁU NUKLEARNEGO IZRAELA}

Początek rozwoju izraelskiego programu badań nad energią nuklearną datuje się na pierwsze lata niepodległości, gdy po odkryciu złóż uranu na pustyni Negev utworzono program stypendialny dla izraelskich fizyków jądrowych studiujących za granicą, a w Ministerstwie Obrony powołano Komisję Energii Jądrowej, odpowiedzialną za kierowanie działalnością badawczą. Już samo umiejscowienie komisji w strukturach Ministerstwa Obrony sugerowało pewne nadzieje, jakie wiązano $\mathrm{z}$ rozwojem tej dziedziny nauki. W latach 50 . XX w. na izraelskich uniwersytetach powołano do życia pierwsze instytuty badań nad energią nuklearną ${ }^{7}$. W tym samym czasie pod auspicjami Komisji Energii Jądrowej otwarto Centrum Badań Nuklearnych Soreq, dysponujące lekkowodnym reaktorem badawczym o niewielkiej mocy (model Israel Research Reactor 1 - IRR-1). W latach 1958-1962, dzięki wsparciu technicznemu otrzymanemu z Francji, niedaleko Dimony na pustyni Negev zbudowano Centrum Badań Jądrowych, wyposażone w jedyny jak dotychczas ciężkowodny reaktor w Izraelu (model Israel Research Reactor 2 - IRR-2) ${ }^{8}$.

Większość współczesnych opracowań wskazuje, że Izraelczycy rozpoczęli dążenia do zdobycia broni nuklearnej w połowie lat 60 . XX w. Jak podają S. Kile i H. Kristensen, do produkcji pierwszych głowic jądrowych posłużył pluton wytworzony w reaktorze pod Dimoną ${ }^{9}$. Podobną wersję przedstawiają m.in. A. Cohen ${ }^{10}$, Y. Cohen ${ }^{11}$ i W. Farr ${ }^{12}$. Kiedy w 1957 r. powołano do życia Międzynarodową Agencję Energii Atomowej (MAEA), Izrael

\footnotetext{
${ }^{5}$ Stownik terminów z zakresu bezpieczeństwa narodowego, Warszawa 2008, s. 126.

${ }^{6}$ AAP-6: Stownik terminów i definicji NATO, NATO Standardization Office 2017, s. 294.

${ }^{7}$ Y. Evron, Israel's nuclear dilemma, London 1994, s. 2.

${ }^{8}$ Y. Cohen, Whistleblowers and the Bomb: Vanunu, Israel and Nuclear Secrecy, London 2005, s. 9.

${ }^{9}$ S. Kile, H. Kristensen, op. cit., s. 278.

${ }^{10}$ A. Cohen, The worst-kept secret: Israel's bargain with the bomb, New York 2010, s. 57-58.

${ }^{11}$ Y. Cohen, op. cit., s. 9-10.

${ }^{12}$ W. Farr, op. cit., s. 2-5.
} 
wstąpił do niej jako jeden z pierwszych członków ${ }^{13}$. Jednocześnie jako jedno z nielicznych państw na świecie nigdy nie ratyfikował Traktatu o Nieproliferacji Broni Nuklearnej z 1968 r. ${ }^{14}$ ani Protokołu Dodatkowego do Umowy o Zabezpieczeniach z 1997 r., nadającego inspektorom MAEA prawo do przeprowadzania niezapowiedzianych i szczegółowych kontroli ośrodków nuklearnych państw-sygnatariuszy. W wyniku osiągniętego kompromisu Izraelczycy poddali kontroli międzynarodowej centrum badawcze Soreq, ale reaktor pod Dimoną wciąż pozostaje zamknięty dla inspektorów MAEA.

Szacuje się, że już przed Wojną Sześciodniową w 1967 r. Izraelczycy posiadali kilka głowic nuklearnych, a niejawną produkcję kontynuowano w następnych dekadach. Ich istnienie nie było początkowo nagłaśniane ani wykorzystywane do celów odstraszania, jednak sam fakt posiadania przez Izrael tajnego ośrodka badawczego w Dimonie został odnotowany przez sąsiednie państwa ${ }^{15}$. Już w latach 60 . XX w. władze amerykańskie wyrażały zaniepokojenie możliwością wyprodukowania przez Izrael głowic jądrowych i naciskały na Izraelczyków, by poddali swoje reaktory kontroli międzynarodowej. W odtajnionym raporcie Centralnej Agencji Wywiadowczej (Central Intelligence Agency - CIA) z 1974 r. stwierdzano wprost, że Izrael dysponuje głowicami jądrowymi i środkami ich przenoszenia ${ }^{16}$. Spekulacje o izraelskiej broni nuklearnej przerodziły się w oficjalną debatę na arenie międzynarodowej w 1986 r. po tzw. aferze Vanunu, kiedy były pracownik ośrodka pod Dimoną, Mordechaj Vanunu, przekazał brytyjskim mediom szczegółowe informacje na temat programu nuklearnego swojej ojczyzny. Od tamtej pory arsenał nuklearny Izraela szacowano najczęściej na kilkadziesiąt głowic, ale według niektórych źródeł liczby te sięgały ponad $200^{17}$.

Według danych z Rocznika SIPRI 2019 arsenał nuklearny Izraela szacowany jest aktualnie na nie więcej niż 80-90 głowic, co w porównaniu z innymi państwami dysponującymi bronią jądrową jest liczbą stosunkowo niską. Wśród 9 państw wskazywanych jako posiadacze broni jądrowej mniejszy arsenał (również oparty na szacunkach) posiada tylko Korea Północna (Vide: rys. 1). Jak wskazują S. Kile i H. Kristensen, około 30\% izraelskiego arsenału nuklearnego stanowią przenoszone drogą lotniczą bomby grawitacyjne, pozostała natomiast część to głowice dostosowane do przenoszenia za pomocą rakiet balistycznych ${ }^{18}$.

\footnotetext{
${ }^{13}$ List of Member States, IAEA, https:/www.iaea.org/about/governance/list-of-member-states (21.08.2019).

${ }^{14}$ Treaty on the Non-Proliferation of Nuclear Weapons, dalej: NPT.

15 Potwierdzają to m.in. egipskie plany operacyjne z 1967 r., uwzględniające reaktor pod Dimoną jako cel strategiczny.

${ }^{16}$ Special National Intelligence Estimate: Prospects for Further Proliferation of Nuclear Weapons, CIA Report No. SNIE 4-1-74, https://nsarchive2.gwu.edu/NSAEBB/NSAEBB240/snie.pdf (21.08.2019).

${ }^{17}$ W. Farr, op. cit., s. 12; Y. Evron, op. cit., s. 10; A. Cohen, op. cit., s. XXVII.

${ }^{18}$ S. Kile, H. Kristensen, op. cit., s. 278.
} 


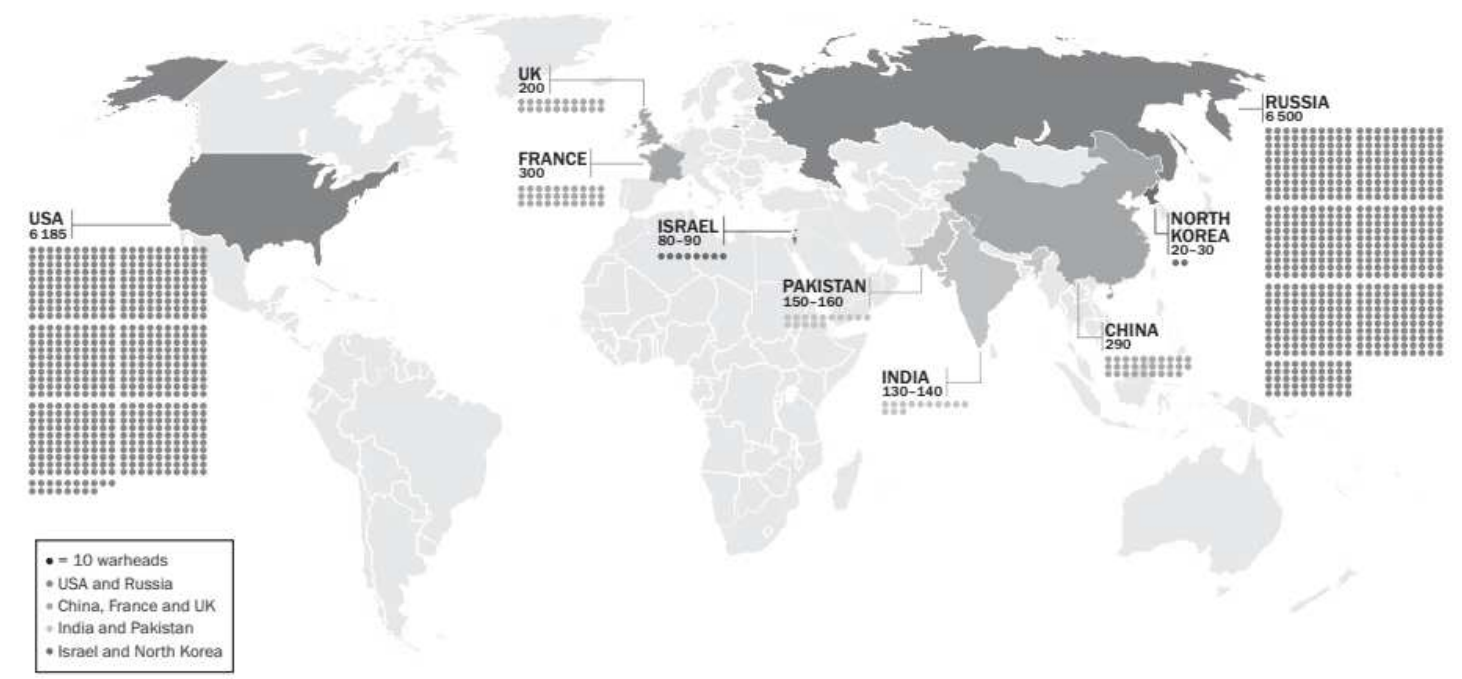

Rysunek 1. Szacowany arsenał nuklearny Izraela na tle innych państw dysponujących bronią jądrową Źródło: SIPRI Yearbook 2019: Armaments, Disarmament and International Security, Stockholm 2018.

Ze względu na brak oficjalnych komunikatów władz izraelskich, dane podawane przez różne ośrodki badawcze bazują na szacunkowych ilościach plutonu, który może zostać wyprodukowany przez reaktor pod Dimoną oraz na analizie rozwoju środków przenoszenia broni jądrowej. Szacunki bazujące tylko na ilości plutonu są zwykle zawyżone - zakładają, że cały dostępny pluton jest zużywany do produkcji głowic, nawet jeśli państwo nie posiada wystarczających środków ich przenoszenia. Takie szacunki nie uwzględniają też konieczności utrzymywania rezerw surowca. Na podstawie prostego przeliczania ilości plutonu na ilość bomb w latach 80. i 90. XX w. izraelski arsenał szacowano na ponad 200 głowic, a w maksymalnych szacunkach liczby te sięgały nawet $400^{19}$. Współcześni badacze $\mathrm{z}$ reguły odrzucają takie podejście, a zdolności Izraela do produkcji plutonu używają tylko do określenia maksymalnych granic danych szacunkowych.

W najnowszych analizach najczęściej wskazuje się na rozwój programu produkcji pocisków balistycznych jako główny wskaźnik wielkości i typu izraelskiego arsenału jądrowego. Według podawanych przez SIPRI danych na rok 2018, Izrael posiada 205 samolotów, które można dostosować do przenoszenia bomb jądrowych, a także ok. 25 taktycznych pocisków balistycznych Jerycho II i podobną liczbę strategicznych pocisków balistycznych Jerycho III, przeznaczonych do przenoszenia głowic nuklearnych. Badacze SIPRI podają także, że 6 okrętów podwodnych typu Dolphin, które Izrael zakupił od Niemiec, może zostać uzbrojonych $\mathrm{w}$ przenoszące broń nuklearną pociski manewrujące ${ }^{20}$. Warto jednak podkreślić, że również te szacunki nie są oparte na oficjalnych izraelskich dokumentach. Izraelczycy nawet w przypadku pocisków balistycznych nigdy nie wskazali wprost, że celem ich produkcji jest przenoszenie głowic nuklearnych. Podobnie jak wszystkie inne wymieniane przez SIPRI potencjalne środki

\footnotetext{
${ }^{19}$ H. Kristensen, R. Norris, Israeli nuclear weapons, 2014, „Bulletin of the Atomic Scientists” 2014, Vol. 70(6), s. 102-103; S. Aronson, The politics and strategy of nuclear weapons in the Middle East. Opacity, theory and reality, 1960-1991: An Israeli perspective, New York 1992, s. 131; W. Farr, op. cit., s. 17.

${ }^{20}$ S. Kile, H. Kristensen, op. cit., s. 278. Vide: H. Kristensen, R. Norris, op. cit., s. 102-104.
} 
przenoszenia broni jądrowej, także pociski balistyczne Jerycho II i Jerycho III mogą zostać uzbrojone w głowice konwencjonalne ${ }^{21}$. Nawet sama ilość pocisków balistycznych Jerycho II i III jest liczbą przypuszczalną, ponieważ program ich rozwoju jest w dużej części utajniony. Zarówno dane techniczne, zasięg, jak i ilość pocisków określane są przez badaczy na podstawie szczątkowych informacji ujawnianych przez Izraelczyków ${ }^{22}$.

Już na tym etapie analizy należy więc podkreślić, że stanowiąca podstawę do dalszych rozważań wielkość arsenału nuklearnego pozostaje w sferze domysłów i nie została nigdy potwierdzona żadnymi komunikatami ze strony władz Izraela. Szacunki przedstawiane przez badaczy mogą być zawyżone (lub zaniżone) ze względu na przyjętą z konieczności metodologię, bazującą na możliwościach produkcji i przenoszenia głowic, a nie na wiarygodnych dowodach na ich istnienie w konkretnej liczbie. Takich dowodów zaś nie będzie tak długo, jak długo Izrael pozostanie poza reżimem kontroli ustanowionym przez NPT.

\section{IZRAELSKA STRATEGIA ODSTRASZANIA NUKLEARNEGO}

Rozważania o izraelskim odstraszaniu nuklearnym warto rozpocząć od wyjaśnienia terminu „odstraszanie”. Według Słownika terminów z zakresu bezpieczeństwa narodowego odstraszanie jest ,jedną z funkcji systemu obronnego państwa, której istotą jest przekonanie strony przeciwnej o nieopłacalności podejmowania działań zbrojnych” ${ }^{\text {23 }}$. R. Szpyra podaje również, że „odstraszanie ma zapobiec wszelkim formom wykorzystania siły przez stronę przeciwną" 24 . Zgodnie z poglądami A. Beaufre'a, „odstraszanie osiąga się dzięki posiadaniu ogółu środków stanowiących wystarczającą groźbę, za pomocą których dąży się do uzyskania efektu psychologicznego"25. Analogicznie, odstraszanie nuklearne oznacza osiąganie takiego efektu poprzez wykorzystanie broni nuklearnej i opiera się na dwóch zasadniczych warunkach: wiarygodnej zdolności odpowiedzi jądrowej w sytuacji niespodziewanego ataku oraz postrzeganej jako pewna woli odwetu ${ }^{26}$. Jak można jednak zauważyć, w przypadku Izraela potwierdzenie posiadania broni jądrowej nie jest niezbędne do zaistnienia odstraszania nuklearnego. Opisana w kolejnej części opracowania strategia odstraszania dlatego właśnie jest nietypowa, że opiera się tylko na przypuszczeniu, iż izraelska broń nuklearna istnieje.

W literaturze przedmiotu izraelska strategia odstraszania nuklearnego często opisywana jest hebrajskim wyrazem amimut, oznaczającym dosłownie „dwuznaczność”, „niejawność”, „nieprzejrzystość"27. W pewnym sensie zaprzecza ona typowym teoriom odstraszania, zakładającym, że to właśnie uświadomienie przeciwnikom istnienia własnego potencjału

\footnotetext{
${ }^{21}$ K.A. Al Bu-Ainnain, Proliferation assessment of ballistic missiles in the Middle East, Dubai 2009, s. 15-16.

${ }^{22}$ A. Cohen, op. cit., s. 287-288.

${ }^{23}$ Słownik terminów..., op. cit., s. 85.

${ }^{24}$ R. Szpyra, Bezpieczeństwo militarne państwa, Warszawa 2012, s. 174.

${ }^{25}$ A. Beaufre, Wstep do strategii. Odstraszanie i strategia, Warszawa 1968, s. 138.

${ }^{26}$ R. Szpyra, op. cit., s. 173.

${ }^{27}$ Ibidem, s. X; O. Israeli, Israel's nuclear amimut policy and its consequences, „Israel Affairs” 2015, Vol. 21(4), s. 542; M. Raska, Beyond the "Bomb in the Basement": Israel's Nuclear Predicament and Policy Options, „Asian Journal of Public Affairs” 2011, Vol. 1(2), s. 22.
} 
nuklearnego i jego potęgi skutecznie zniechęca ich do podejmowania działań agresywnych. Jak podaje O. Israeli, strategia amimut opiera się na dwóch filarach:

- utrzymywaniu w tajemnicy faktycznego poziomu rozwoju programu nuklearnego i potencjału broni jądrowej (co przekłada się na brak publicznych deklaracji posiadania tego typu broni i nieprzeprowadzanie testów jądrowych),

- budowaniu wizerunku państwa, które potencjalnie może posiadać broń jądrową, poprzez celowe ,przecieki” informacyjne, pogłoski oraz oświadczenia decydentów politycznych, pośrednio sugerujące możliwość istnienia potencjału nuklearnego ${ }^{28}$.

A. Cohen zauważa, że Izrael jest jak dotąd jedynym z państw uznawanych za posiadaczy broni jądrowej, które nigdy otwarcie nie demonstrowało ani istnienia swojego potencjału nuklearnego, ani jego siły rażenia. Arsenał nuklearny nie jest wykorzystywany w sposób otwarty w celu budowania prestiżu państwa na arenie międzynarodowej ani w komunikacji pomiędzy władzą a obywatelami Izraela. Nie pojawia się też praktycznie w wewnętrznej debacie publicznej $^{29}$. Mimo że zagadnienia z zakresu bezpieczeństwa państwa stanowią kluczowy element każdej kampanii wyborczej w Izraelu, to temat broni nuklearnej w ogóle nie pojawia się w programach politycznych, postulatach kandydatów czy debatach telewizyjnych - wodróżnieniu od szeroko komentowanych pozostałych elementów systemu obronnego. Według A. Cohena jest to charakterystyczna dla izraelskiej kultury politycznej swoista „autocenzura”, będąca efektem powszechnego konsensusu wszystkich ugrupowań politycznych oraz obywateli. Nie oczekują oni otwartej debaty na ten temat, zdając sobie sprawę z wagi owej tajemnicy dla zapewnienia bezpieczeństwa ich państwa ${ }^{30}$. Istotną rolę w utrzymywaniu zagadnienia izraelskiej broni nuklearnej poza sferą publiczną odgrywa także urząd cenzora wojskowego - oddziału wywiadu wojskowego, odpowiedzialnego m.in. za ochronę tajemnic państwowych oraz wrażliwych danych wojskowych przed przenikaniem do mediów ${ }^{31}$.

W 1964 r. ówczesny premier Izraela Levi Eszkol wygłosił przemówienie, w którym stwierdził, że „Izrael nie będzie krajem, który jako pierwszy wprowadzi broń jądrową na Bliski Wschód”32. Co znamienne, według większości badaczy to właśnie za rządów Leviego Eszkola Izraelczycy wyprodukowali pierwsze głowice nuklearne, a cytat ten stał się dewizą strategii amimut, której aktualność potwierdzają wypowiedzi późniejszych władz Izraela. Identyczne oświadczenia w latach osiemdziesiątych wygłaszali m.in. Icchak Szamir, Szimon Peres oraz liczni dyplomaci ${ }^{33}$. W 2011 r. w wywiadzie dla stacji CNN premier Izraela, Benjamin Netanjahu, zapytany o broń jądrową swojego państwa (w kontekście sprzeciwu Izraela wobec rozwoju programu nuklearnego Iranu), powtórzył słynne słowa Eszkola. Dodał, że „Izrael [w odróżnieniu od Iranu - przyp. aut.] nie stwarza dla nikogo zagrożenia, nie wzywa do anihilacji kogokolwiek

\footnotetext{
${ }^{28}$ O. Israeli, op. cit., s. 545.

${ }^{29}$ A. Cohen, op. cit., s. XXVII.

${ }^{30}$ Ibidem, s. XXIX.

${ }^{31}$ G. Giles, Continuityand Change in Israel's Strategic Culture, Washington 2006, s. 22.

${ }^{32}$ Cyt. za: S. Aronson, op. cit., s. 90 (tłum. własne).

${ }^{33}$ Y. Cohen, op. cit., s. 10.
} 
i nie wspiera terroryzmu”34. Stwierdził ponadto, że „to nie Izrael grozi innym państwom zniszczeniem ich bronią nuklearną, ale sam jest obiektem takich gróźb"35. W kolejnych latach, a szczególnie w czasie negocjacji tzw. Wspólnego Kompleksowego Planu Działania w sprawie irańskiego programu nuklearnego, izraelscy dyplomaci wielokrotnie domagali się transparentności programu badań jądrowych w Iranie. Wszelkie uwagi na temat jej braku po stronie Izraela tłumaczyli strategią, według której Izrael nie będzie pierwszym państwem, jakie wprowadzi do regionu broń jądrową - a więc jej nie posiada ${ }^{36}$.

Utrzymywanie własnej broni jądrowej w tajemnicy, przy jednoczesnym domaganiu się transparentności i pełnej kontroli nad programami nuklearnymi innych państw, stanowi celowe i długofalowe działanie w ramach strategii amimut. Wiąże się to z kolejnym istotnym elementem izraelskiej koncepcji odstraszania nuklearnego, jakim jest sformułowana w latach 80. XX w. tzw. „doktryna Begina”. Jest to nieoficjalna koncepcja ${ }^{37}$, której autorstwo przypisuje się ówczesnemu premierowi Menachemowi Beginowi. Według niej Izrael, niezależnie od okoliczności, nie może pozwolić żadnemu wrogiemu państwu na wyprodukowanie lub zdobycie broni masowego rażenia, która mogłaby zostać użyta przeciwko obywatelom państwa izraelskiego. Koncepcja ta zakłada również, że Izrael użyje wszystkich sił i środków w swojej dyspozycji, jeśli będzie to konieczne do zapobieżenia takiej sytuacji ${ }^{38}$. Można jedynie domniemać, czy „wszystkie środki” oznaczają również broń jądrową. Do lat dziewięćdziesiątych założenia „doktryny Begina” odnoszono do wszystkich rodzajów broni masowego rażenia. W jej współczesnym rozumieniu ogranicza się je zwykle do przeciwdziałania proliferacji broni nuklearnej w regionie Bliskiego Wschodu $^{39}$. W praktyce przekłada się ona na stosowanie przez Siły Obronne Izraela ${ }^{40}$ jednostronnych, nieautoryzowanych przez organy ONZ działań militarnych w stosunku do państw zagrażających izraelskiemu monopolowi jądrowemu w regionie. Typowe przykłady realizacji tej niepisanej doktryny to izraelski atak lotniczy na iracki reaktor Osirak w $1981 \mathrm{r}$. (operacja „Opera”) oraz na syryjski ośrodek badań jądrowych w Dajr az-Zaur w 2007 r. (operacja „Orchidea”) ${ }^{41}$. „Doktryna Begina” wpisuje się również w szersze założenia izraelskiej doktryny wojennej, zakładającej możliwość uderzeń wyprzedzających i działań prewencyjnych w przypadku, gdy konieczne jest przeniesienie działań zbrojnych na terytorium przeciwnika lub gdy zagrożone jest przetrwanie państwa ${ }^{42}$.

\footnotetext{
34 Interview with PM Netanyahu on CNN-Piers Morgan Tonight, Israel Ministry of Foreign Affairs, https://mfa.gov.il/MFA/PressRoom/2011/Pages/Interview_PM_Netanyahu_CNN_17-Mar-2011.aspx (18.09.2019).

${ }^{35}$ Ibidem.

${ }^{36}$ Vide: J. Zych, Wspólny Kompleksowy Plan Działania z 2015 r. w sprawie irańskiego programu nuklearnego - perspektywa Izraela, „Rocznik Bezpieczeństwa Międzynarodowego” 2017, Vol. 11(1).

${ }^{37}$ Warto podkreślić, że izraelski rząd nigdy oficjalnie nie potwierdził przyjęcia takiej doktryny - jej zakres i założenia badacze tematu zgodnie wywodzą z publicznych wypowiedzi władz Izraela oraz z praktyki działania w stosunku do innych państw w regionie, dążących do rozwoju potencjału nuklearnego. Vide: S. Brom, Is the Begin Doctrine Still a Viable Option for Israel? [w:] Getting ready for a nuclear-ready Iran, Carlisle 2005, s. 137.

${ }^{38}$ O. Israeli, op. cit., s. 546.

${ }^{39}$ Vide: A. Yadlin, The Begin Doctrine: The Lessons of Osirak and Deirez-Zor, „INSS Insight”2018, No. 1037.

${ }^{40}$ Israel Defense Forces, dalej: IDF.

${ }^{41}$ Ibidem, s. 2; P. Ford, Israel's Attack on Osiraq: a Model for Future Preventive Strikes?, Monterey 2004, s. 57.

${ }^{42}$ A. Cohen, op. cit., s. 224.
} 
Odniesienia do „doktryny Begina” coraz częściej pojawiają się w analizach na temat stosunku Izraela do ambicji nuklearnych Iranu. Izraelscy badacze związani z Instytutem Studiów nad Bezpieczeństwem Narodowym w Tel Awiwie w ostatnich latach opublikowali szereg artykułów na temat możliwości wyprowadzenia uderzeń wyprzedzających przeciwko irańskim ośrodkom nuklearnym, aby zapobiec wyprodukowaniu przez wrogie państwo głowic jądrowych. Analizy zawierające scenariusze takiego ataku oraz jego prawno-międzynarodowych konsekwencji opublikowali m.in. S. Brom ${ }^{43}$, R. Sabel ${ }^{44}$, R. Pedatzur ${ }^{45}$ i A. Yadlin ${ }^{46}$. Również publiczne oświadczenia przedstawicieli najwyższych władz Izraela w ostatniej dekadzie sugerują, że prewencyjne zniszczenie ośrodków nuklearnych jest (lub było) jedną z opcji branych pod uwagę w sytuacji, gdyby społeczność międzynarodowa nie zapobiegła dalszemu rozwojowi irańskiego programu wzbogacania uranu. Nie można również wykluczyć, że sugestie rozwiązania militarnego są celowym zabiegiem izraelskiej dyplomacji, niezwiązanym z realnym planem takiego ataku. W sytuacji, gdy Izrael zrealizował już dwukrotnie założenia „doktryny Begina” w praktyce, nawet zawoalowane groźby ataku na Iran (który wymagałby zdecydowanie większych sił i środków niż operacje wojskowe w 1981 r. i 2007 r.) traktowane są poważnie ${ }^{47}$. Obawa przed powtórzeniem takich działań w stosunku do Iranu sprawia, że postulaty Izraela co do utrzymania sankcji gospodarczych oraz poddania irańskiego programu nuklearnego ścisłej kontroli mają szansę przebicia w debacie społeczności międzynarodowej.

Fakt, że Izrael jest domniemanym posiadaczem co najmniej kilkudziesięciu głowic nuklearnych dodatkowo sprawia, że każda groźba zastosowania rozwiązań militarnych traktowana jest przez społeczność międzynarodową jako potencjalne źródło konfliktu na nieprzewidywalną skalę. To z kolei wiąże się z następnym elementem izraelskiej strategii odstraszania nuklearnego, jakim jest utrzymywanie potencjalnych przeciwników i kluczowych graczy na arenie międzynarodowej $\mathrm{w}$ niepewności co do własnych zamiarów, związanych $\mathrm{z}$ użyciem (istniejącej lub nie) broni jądrowej.

Zgodnie z klasyczną teorią odstraszania A. Beaufre'a, samo posiadanie przez państwo broni nuklearnej nie gwarantuje, że będzie ona odstraszać potencjalnych agresorów. Aby strategia odstraszania nuklearnego była skuteczna, muszą jeszcze zostać spełnione następujące warunki:

- utrzymywanie przeciwnika w niepewności co do zamiarów posiadacza broni jądrowej i jego racjonalności,

- uwiarygodnienie możliwości odwetu - wola decydentów do użycia broni jądrowej, jeśli będzie to konieczne,

- siła rażenia i zdolność przenikania przez systemy obrony - wystarczająca z psychologicznego punktu widzenia do wywołania w przeciwniku strachu,

\footnotetext{
${ }^{43}$ S. Brom, op.cit.

${ }^{44}$ R. Sabel, The Legality of an Attack against Iranian Nuclear Facilities, „INSS Insight „, 2012, No. 345.

${ }^{45}$ R. Pedatzur, The Iranian Nuclear Threat and the Israeli Options, „Contemporary Security Policy” 2007, Vol. 28(3).

${ }^{46}$ A. Yadlin, op. cit.

${ }^{47}$ G. Steinberg, Iran in the Israeli Threat Perception[w:] A. Tarzi (ed.), The Iranian Puzzle Piece: Understanding Iran in the Global Context, Quantico 2009, s. 75.
} 
- możliwość odpowiedzi nawet w sytuacji, gdy przeciwnik uderzy pierwszy (zdolność do przetrwania) $)^{48}$.

Skuteczne odstraszanie nuklearne opiera się więc na stworzeniu sytuacji, w której wiarygodna groźba odpowiedzi i nieuchronność zniszczeń (oraz ich nieprzewidywalna skala) sprawiają, że ryzyko zaatakowania posiadacza takiej broni jest zbyt duże, a jego podejmowanie nieopłacalne ${ }^{49}$. Kluczowe dla wiarygodnego odstraszania utrzymywanie przeciwnika w niepewności co do własnych zamiarów i racjonalności w przypadku Izraela znalazło swoje odbicie w tzw. „opcji Samsona” (nazywanej też „strategią Samsona”). To spopularyzowane przez S. Hersha określenie nawiązuje do biblijnej historii Samsona, który po pojmaniu przez Filistynów i doprowadzeniu do świątyni wroga, obalił jej filary, po czym budowla runęła, zabijając Samsona i wszystkich zgromadzonych Filistynów. Nuklearna „opcja Samsona” odnosi się do teorii, według której w przypadku niemożności prowadzenia dalszej obrony państwa przed inwazją zbrojną Izrael odpowie zmasowanym atakiem jądrowym na terytorium przeciwnika, nawet za cenę własnego zniszczenia ${ }^{50}$. Nawiązując do tej teorii, O. Israeli podaje, że ewentualne użycie przez Izrael broni jądrowej byłoby ostatecznością w sytuacji, gdy inne środki militarne zawiodą - ale samo przygotowanie państwa na taką ewentualność pozwala na zwiększenie potencjału odstraszania i uświadomienie przeciwnikom, że atak na Izrael może wiązać się $\mathrm{z}$ nieprzewidywalnym odwetem na ogromną skalę ${ }^{51}$.

Niektórzy badacze porównują izraelską „opcję Samsona” do doktryny wzajemnie zagwarantowanego zniszczenia (Mutual Assured Destruction - MAD). Ta sformułowana po kryzysie kubańskim doktryna zakładała, że świadomość potężnego odwetu nuklearnego i anihilacji własnej ludności zahamuje obie strony zimnowojennego konfliktu przed wykonaniem pierwszego uderzenia, a dzięki temu - paradoksalnie - pozwoli na stabilizację sytuacji międzynarodowej i utrzymanie pokoju ${ }^{52}$. Pomiędzy założeniami „opcji Samsona” a doktryną MAD istnieją jednak dwie znaczące różnice. Po pierwsze, doktryna MAD odnosiła się do rywalizacji między dwoma mocarstwami nuklearnymi, dysponującymi na tyle potężnym arsenałem i możliwościami odwetu, aby móc się nawzajem zniszczyć. W przypadku nuklearnego monopolu Izraela w regionie groźba odwetu z użyciem broni jądrowej odnosi się do państw, które same takiej broni nie posiadają. Celem odstraszania jest więc zapobieżenie jakiejkolwiek agresji na terytorium Izraela, nawet z użyciem środków konwencjonalnych. Po drugie, żadne z państw uznawanych w różnych okresach istnienia współczesnego Izraela za wrogie ${ }^{53}$ nie posiadało broni nuklearnej. Nie zachodziła więc możliwość stworzenia owej równowagi sił, która w czasie zimnej

\footnotetext{
${ }^{48}$ A. Beaufre, op. cit., s.76-80.

${ }^{49}$ Ibidem, s. 148-199.

${ }^{50}$ S. Hersh, The Samson Option: Israel's Nuclear Arsenal and American Foreign Policy, New York 1991, 136-137.

${ }^{51}$ O. Israeli, op. cit., s. 546.

${ }^{52}$ T. Delpech, Nuclear Deterrence in the 21st Century. Lessons from Cold War for a New Era of Strategic Piracy, Santa Monica 2012, s. 35-36.

${ }^{53}$ Wśród państw uznawanych za dysponujące bronią jądrową, niepodległości Izraela nie uznają Korea Północna i Pakistan. W odróżnieniu od części państw bliskowschodnich nie wysuwają one jednak gróźb zniszczenia państwa żydowskiego, dlatego też przez izraelskich decydentów nie są postrzegane jako zagrożenie. Vide: T. Delpech, op. cit., s. 30 .
} 
wojny gwarantowała powstrzymywanie się obu stron od otwartej konfrontacji. Kreowanie wizerunku Izraela jako państwa gotowego wdrożyć w życie „opcję Samsona” w przypadku braku alternatywy służy więc nie tyle zapobieganiu wojnie samej w sobie, lecz także utrzymywaniu potencjalnych przeciwników $\mathrm{w}$ niepewności co do racjonalności izraelskich decydentów w obliczu agresji zbrojnej. S. Hersh zauważa, że z perspektywy celów strategicznych Izraela ta niepewność musi być na tyle wiarygodna, aby pozostałe państwa w regionie - mimo ciągłej rywalizacji - pogodziły się z istnieniem państwa izraelskiego na Bliskim Wschodzie ${ }^{54}$.

Rzetelna ocena siły rażenia izraelskich głowic nuklearnych jest niemożliwa ze względu na brak potwierdzonych danych technicznych. Nieliczni badacze, którzy pokusili się o ich określenie w postaci danych szacunkowych, sugerują, że mogą to być głowice mocy od ok. 20 kiloton (np. W. Farr ${ }^{55}$, C. Cozic i K. Swisher ${ }^{56}$ ), aż do 100 lub nawet 200 kiloton (L. Spector ${ }^{57}$ ). Zdolność do przenikania przez systemy obrony przeciwników zależy oczywiście od tego, jakie państwo zostanie uznane za potencjalny cel ataku (lub odwetu) nuklearnego. Izraelczycy nigdy wprost nie wskazali państwa, które mogłoby w określonej sytuacji stać się takim celem, ponieważ wiązałoby się to z odstąpieniem od strategii amimut. Na stworzenie bardzo ogólnego zarysu zdolności do przeprowadzania uderzeń nuklearnych pozwala więc jedynie analiza środków przenoszenia głowic i ich zasięgu. Jak można zauważyć w zamieszczonej poniżej tabeli, Izraelczycy dysponują obecnie wszystkimi elementami „triady nuklearnej” - środkami przenoszenia głowic jądrowych, pozwalającymi na przeprowadzanie uderzeń z powietrza (lotnictwo strategiczne), z lądu (rakietowe pociski balistyczne) oraz z morza (pociski rakietowe, przenoszone przez okręty podwodne).

\begin{tabular}{|c|c|c|c|c|}
\hline & Тур & $\begin{array}{c}\text { Wprowadzenie } \\
\text { do służby }\end{array}$ & Zasięg & Uwagi \\
\hline \multirow{3}{*}{ Lotnictwo } & $\begin{array}{c}\mathrm{F}-16 \mathrm{~A} / \mathrm{B} / \mathrm{C} / \mathrm{D} / \mathrm{I} \\
\text { Fighting Falcon }\end{array}$ & 1980 & $1600-4220 \mathrm{~km}$ & \\
\hline & $\begin{array}{l}\text { F-15I Ra'am } \\
\text { (Thunder) }\end{array}$ & 1988 & 3500 & \\
\hline & F-35I Adir & 2017 & $2220 \mathrm{~km}$ & \\
\hline \multirow{2}{*}{$\begin{array}{c}\text { Pociski } \\
\text { balistyczne }\end{array}$} & Jericho II & 1984-1985 & powyżej $1500 \mathrm{~km}$ & Dane szacunkowe \\
\hline & Jericho III & $2011(?)$ & $4800-11500 \mathrm{~km}$ & Dane szacunkowe \\
\hline $\begin{array}{c}\text { Okręty } \\
\text { podwodne }\end{array}$ & Dolphin-1/-2 & $2000-2002$ & $\begin{array}{c}\text { Okręty: ok. } 13000 \mathrm{~km} \\
\text { (zanurzenie do } 30 \mathrm{dni} \text { ) } \\
\text { Pociski rakietowe: do } \\
1500 \mathrm{~km}^{*}\end{array}$ & $\begin{array}{c}\text { Dane szacunkowe. } \\
\text { *Zasięg uzależniony od } \\
\text { typu pocisków, w które } \\
\text { uzbrojone zostaną okręty }\end{array}$ \\
\hline
\end{tabular}

Tabela1:Potencjalne środkiprzenoszeniabronijądrowejprzezSiłyObronneIzraela.

Źródło: opracowanie własne na podstawie: A. Feickert, Missile Survey: Ballistic and Cruise Missiles of Foreign Countries, Washington 2005; H. Kristensen, R. Norris, Israelinuclear weapons, 2014, „Bulletin of the Atomic Scientists" 2014, Vol. 70(6); Missiles of Israel, Center for Strategic and International Studies, https://missilethreat.csis.org/missile/jericho-3 (20.09.2019).

\footnotetext{
${ }_{55}^{54}$ S. Hersh, op. cit., s. 136.

${ }^{55}$ W. Farr, op. cit., s. 9.

${ }^{56}$ C. Cozic, K. Swisher, Nuclear Proliferation: Opposing Viewpoints, New York 1992, s. 131.

${ }^{57}$ L. Spector, Nuclear proliferation: who's next?, „Bulletin of the Atomic Scientists” 1987, Vol. 4(7), s. 18.
} 
O ile w przypadku wymienionych w tabeli samolotów zasięg maksymalny upubliczniany jest przez ich amerykańskich producentów, o tyle zasięg izraelskich pocisków balistycznych Jerycho oraz potencjalnego uzbrojenia okrętów podwodnych typu Dolphin pozostaje szacunkowy. Kluczowe dla izraelskiej strategii odstraszania są okręty podwodne, zdolne do przenoszenia broni jądrowej. W odróżnieniu od mocarstw o rozległych granicach, w przypadku ataku jądrowego na główne ośrodki miejskie niewielkiego Izraela mogłoby dojść do jego całkowitego zniszczenia, co uniemożliwiłoby jakikolwiek odwet. Jak podaje A. Cohen, jest to główna przyczyna obrony izraelskiego monopolu nuklearnego za wszelką cenę ${ }^{58}$. Problem z uwiarygodnieniem możliwości przetrwania i odwetu częściowo niweluje możliwość przeprowadzenia go przez załogi okrętów podwodnych, które - nawet w przypadku zniszczenia izraelskich samolotów i wyrzutni rakiet balistycznych na lądzie - byłyby w stanie przetrwać i dosięgnąć terytorium przeciwnika ${ }^{59}$. Warto podkreślić również znaczenie rozwoju izraelskiego programu pocisków balistycznych dla strategii odstraszania. Jak wskazują dostępne dane, zasięg rakiet Jerycho III pozwala zaklasyfikować je jako pociski międzykontynentalne. Nawet przy przyjęciu minimalnych szacunków (ok. 4800 km) w ich zasięgu znajdzie się cały Bliski Wschód, ponad połowa Afryki, Europa oraz część Rosji i południowo-zachodniej Azji ${ }^{60}$.

\section{MIEJSCE BRONI JĄDROWEJ W IZRAELSKIEJ STRATEGII ODSTRASZANIA}

W 2015 r. po raz pierwszy w historii upubliczniono Strategie Sit Obronnych Izraela. Odstraszanie określono $\mathrm{w}$ niej jako jedno z pięciu podstawowych zadań sił zbrojnych, wynikających z doktryny strategicznej (obok wczesnego ostrzegania, prowadzenia działań obronnych, pokonania przeciwnika i ostatecznego zwycięstwa) ${ }^{61}$. W rozdziale poświęconym strategii odstraszania autorzy dokumentu wskazali główne warunki, jakie musi spełnić Izrael, aby skutecznie zniechęcać potencjalnych przeciwników do podejmowania działań agresywnych. Przede wszystkim, wskazano na konieczność dostosowania metod odstraszania do nowych zagrożeń związanych $\mathrm{z}$ działalnością podmiotów niepaństwowych. Jak zauważyli autorzy dokumentu, inicjatywa strategiczna IDF i ofensywny charakter działań zbrojnych (przez lata zapewniające skuteczne odstraszanie) straciły na znaczeniu $\mathrm{w}$ konfrontacji $\mathrm{z}$ organizacjami terrorystycznymi, kierującymi się inną logiką niż państwa. W dokumencie przyjęto również zasadę dwutorowości odstraszania. $\mathrm{Z}$ jednej strony, w czasie pokoju, powinno być ono bardzo uogólnione i skierowane do wszystkich potencjalnych przeciwników. Z drugiej, w przypadku kryzysu lub wojny, powinno być dostosowane do konkretnego przeciwnika i specyfiki działania oraz jego możliwości militarnych ${ }^{62}$.

\footnotetext{
${ }^{58}$ A. Cohen, op. cit., s. 38.

${ }^{59}$ M. Raska, op. cit., s. 23.

${ }^{60}$ Israel's Ballistic and Cruise Missiles, Center for Strategic and International Studies, https://missilethreat.csis.org/country/israel (20.09.2019).

${ }^{61}$ Deterring Terror - How Israel Confronts the Next Generation of Threats. English Translation of the Official Strategy of the Israel Defense Forces, Cambridge 2016, s. VI.

${ }^{62}$ Ibidem, s. 24.
} 
W myśl Strategii IDF izraelska koncepcja odstraszania opiera się na:

1) stworzeniu wiarygodnej groźby przeprowadzenia przez IDF operacji militarnej na wielką skalę - skutkującej poważnymi stratami, jeśli przeciwnik zaatakuje Izrael - poprzez:

a) rozwijanie zdolności sił zbrojnych do zadawania strat przeciwnikowi oraz częściowe ujawnianie tego potencjału w celu budowania wizerunku państwa zdolnego i gotowego do podjęcia walki zbrojnej,

b) budowanie opinii publicznej, ukazującej gotowość Izraela do podjęcia ryzyka w obliczu zagrożenia,

c) przeprowadzanie przez IDF operacji zbrojnych o ograniczonej skali, które stanowią dla przeciwnika przestrogę przed podejmowaniem działań agresywnych,

2) rozbudowie systemu obronnego, aby przekonać przeciwników do bezcelowości agresji,

3) rozwoju zdolności do dezorganizacji działań przeciwnika i ich powstrzymywania ${ }^{63}$.

Co zrozumiałe w kontekście strategii amimut, oficjalna Strategia IDF nie uwzględnia potencjału nuklearnego i skupia się na roli sił konwencjonalnych. Pozwala jednak na wyciągniecie ogólnych wniosków dotyczących miejsca broni jądrowej w koncepcji odstraszania. Uwagę zwraca przede wszystkim wzrastająca rola podmiotów niepaństwowych jako przeciwników Izraela, w przypadku których odstraszanie nuklearne nie może spełniać swojej podstawowej roli. Ugrupowania terrorystyczne nie ponoszą odpowiedzialności za konkretne terytorium, ludność czy infrastrukturę, a dla celów propagandowych niejednokrotnie dążą wręcz do maksymalizacji liczby ofiar po stronie ludności, wśród której funkcjonują. W ich przypadku groźba odwetu nuklearnego nie przedstawia większej wartości jako czynnik odstraszający ${ }^{64}$. W przypadku działającego $\mathrm{w}$ rozproszeniu przeciwnika trudno byłoby wskazać cel takiego uderzenia. Jednocześnie ataki terrorystyczne - choćby o masowej skali - nie stanowią nigdy zagrożenia dla przetrwania państwa, przez co użycie w odpowiedzi broni nuklearnej byłoby nie tylko nieproporcjonalne i bezcelowe, lecz także wiązałoby się z nieopłacalnymi reperkusjami międzynarodowymi. Powszechna świadomość tych uwarunkowań sprawia, że arsenał nuklearny nie zniechęca ugrupowań terrorystycznych do ataków na dysponujące nim państwo. W przypadku Izraela jest to szczególnie zauważalne. O ile obawa przed domniemaną izraelską bronią jądrową może hamować wrogie państwa w regionie przed zbrojną inwazją, o tyle nie powstrzymuje Hezbollahu, Hamasu czy Palestyńskiego Islamskiego Dżihadu przed przeprowadzaniem zamachów i ostrzałem rakietowym rejonów przygranicznych w Izraelu - brakuje wiarygodnej groźby odwetu $^{65}$. Według A. Golova, w odniesieniu do niepaństwowych czy quasi-państwowych przeciwników Izraela zdecydowanie skuteczniejsze pozostaje odstraszanie za pomocą precyzyjnych środków konwencjonalnych ${ }^{66}$.

\footnotetext{
${ }^{63}$ Ibidem, s. 25.

${ }^{64}$ R. Kopeć, P. Mazur, Odstraszanie militarne w XXI wieku Polska - NATO - Rosja, Kraków 2017, s. 25.

${ }^{65}$ A. Golov, Israeli Deterrence in the 21st Century, Tel Aviv 2016, s. 94.

${ }^{66}$ Ibidem, s. 84.
} 
Bazując na wcześniejszych rozważaniach można wysnuć wniosek, że izraelska broń jądrowa może służyć celom odstraszania tylko w przypadku uznanych za potencjalne zagrożenie militarne aktorów państwowych. Strategia IDF z 2015 r. określa cztery główne kategorie podmiotów, stanowiących zagrożenie polityczno-militarne dla Izraela:

1) Podmioty państwowe - w tym w otoczeniu bliższym (Liban) i dalszym (Iran) ${ }^{67}$;

2) Państwa upadłe lub upadające (Syria),

3) Podmioty sub-państwowe/quasi-państwowe - powiązane z konkretnym obszarem i zamieszkującą go ludnością, ale nie będące państwami i nie stosujące się do zasad prawa międzynarodowego, obowiązujących państwa (Hamas i Hezbollah),

4) Organizacje terrorystyczne niepowiązane $\mathrm{z}$ żadnym państwem lub ludnością (Islamski Dżihad, Palestyński Islamski Dżihad, ISIS i inne) ${ }^{68}$.

Jak można zauważyć, podmioty wymienione w dwóch ostatnich punktach z założenia nie podlegają zasadom odstraszania nuklearnego. Również Syria (uznawana za zagrożenie nie ze względu na groźbę agresji, a z powodu rozkładu struktur państwowych i udostępnianie terytorium do transportu irańskiej broni do Libanu) nie jest obecnie adresatem izraelskiego odstraszania jądrowego. A. Terill stwierdza wprost, że izraelska broń nuklearna w aktualnej sytuacji geopolitycznej służy głównie odstraszaniu jednego państwa - Iranu. Powołuje się m.in. na ćwiczenia wojskowe izraelskiego lotnictwa, w ramach których odtwarzano warunki ataku powietrznego na Iran. Zakłada również, że Izraelczycy byliby skłonni użyć broni jądrowej, gdyby zaistniało realne ryzyko złamania przez Iran izraelskiego monopolu jądrowego w regionie $^{69}$. Inną opinię przedstawia m.in. Y. Evron, który wskazuje, że Izrael w dalszym ciągu opiera swoją strategię odstraszania (w tym odstraszania adresowanego do Iranu) na rozwoju potencjału konwencjonalnego, którego użycie jest bardziej prawdopodobne - a więc i wiarygodność odwetu w przypadku zagrożenia jest większa ${ }^{70}$.

Istotne znaczenie dla niniejszej analizy mają wspomniane w Strategii IDF operacje zbrojne, które mają stanowić dla przeciwników przestrogę przed podejmowaniem agresji na terytorium Izraela i stanowią jeden z filarów odstraszania. W izraelskiej nomenklaturze operacje te nazywane są „kampaniami między wojnami” (Campaign Between Wars - CBW) i odnoszą się do operacji zbrojnych na niewielką skalę, których podstawowym celem jest tymczasowe osłabienie przeciwnika, uniemożliwienie mu zbrojeń, utrwalenie efektów zwycięstwa Izraela w poprzedniej wojnie lub przygotowanie sprzyjających warunków do przyszłego starcia militarnego ${ }^{71}$. Ich dodatkowym skutkiem jest wzmocnienie wizerunku

\footnotetext{
${ }^{67}$ Co warto podkreślić, Strategia IDF wprost wskazuje poszczególne państwa uważane za wrogie - wszystkie inne państwa w regionie, mimo że w większości nie uznają niepodległości Izraela, nie zostały uznane za realne zagrożenie militarne.

${ }^{68}$ Deterring Terror - How Israel..., op. cit., s. 4.

${ }^{69}$ A. Terill, Deterrence in the Israeli-Iranian Strategic Standoff, „Parameters” 2009, Vol. 39(1), s. 87.

${ }^{70}$ Y. Evron, op. cit., s. 11.

${ }^{71}$ Deterring Terror - How Israel ..., op. cit., s. 25.
} 
Izraela jako państwa posiadającego wystarczający potencjał do niszczenia ważnych celów na terytorium przeciwnika w dowolnym czasie i miejscu. Jak zauważa Y. Lappin, izraelskie naloty na cele w sąsiednich państwach wzmacniają potencjał odstraszania w stosunku do państw czy organizacji bezpośrednio zaatakowanych, ale także w stosunku do innych aktorów na scenie międzynarodowej ${ }^{72}$. Wielokrotne izraelskie naloty na konwoje transportujące irańskie uzbrojenie przez terytorium Syrii do Libanu przywoływane są często w literaturze jako przykład typowej w ostatnich latach metody odstraszania, stosowanej przez Izraelczyków. Jako rozwiązanie doraźne jest to metoda skuteczniejsza niż odstraszanie nuklearne, które nie powstrzymuje przeciwników przed wspieraniem i zbrojeniem organizacji terrorystycznych czy tworzeniem własnych przyczółków coraz bliżej granic Izraela ${ }^{73}$. Jak widać, domniemanej broni nuklearnej i izraelskiej „opcji Samsona” można przypisać istotne znaczenie w zniechęcaniu wrogich państw do podejmowania prób inwazji zbrojnej czy wręcz zniszczenia całego Izraela, ale w przypadku przeciwników prowadzących walkę za pośrednictwem organizacji terrorystycznych czy w ramach tzw. wojen zastępczych (proxy wars), to odstraszanie konwencjonalne odgrywa wiodącą rolę.

Na koniec warto odnieść się do często poruszanego w literaturze aspektu odstraszania, jakim jest rozszerzone odstraszanie nuklearne Stanów Zjednoczonych. W teorii odstraszania wyróżnia się dwa jego rodzaje: bezpośrednie (odstraszanie od ataku na odstraszającego) i rozszerzone (odstraszanie od ataku na sojusznika państwa odstraszającego) ${ }^{74}$. W przypadku Izraela niektórzy badacze przyjmują założenie, że nawet jeśli nie posiada własnej broni nuklearnej, to i tak w swojej strategii odstraszania uwzględnia odstraszanie nuklearne - tyle, że za pomocą amerykańskiego arsenału Do takich poglądów przychyla się między innymi A. Golov, zaznaczając jednak, że amerykański ,parasol nuklearny” nie jest i nie może być traktowany jako główna gwarancja bezpieczeństwa Izraela. Wiąże się to z brakiem oficjalnych deklaracji użycia broni nuklearnej przez Stany Zjednoczone w przypadku zagrożenia dla egzystencji Izraela, jak również ze ścisłymi powiązaniami USA z innymi państwami bliskowschodnimi, co z kolei osłabia wizerunek Izraela jako kluczowego partnera Amerykanów w regionie ${ }^{75}$. Partnerstwo strategiczne Izraela i Stanów Zjednoczonych podkreślane jest w Strategii IDF jako kluczowe dla umacniania pozycji państwa $\mathrm{i}$ zapewniania mu wsparcia na arenie międzynarodowej ${ }^{76}$. Izraelczycy jednak nigdy nie uznawali wsparcia z zewnątrz za jedyną, pewną gwarancję własnego bezpieczeństwa - nawet w przypadku partnera dysponującego bronią jądrową.

\footnotetext{
${ }^{72}$ Y. Lappin, 'The War Between Wars': Israel vs Iran in Syria, http://fathomjournal.org/the-war-between-warsisrael-vs-iran-in-syria (01.10.2019).

${ }^{73}$ Ibidem; G. Eisenkot, G. Siboni, The Campaign Between Wars: How Israel Rethought Its Strategy to Counter Iran's Malign Regional Influence, https:/www.washingtoninstitute.org/policy-analysis/view/the-campaignbetween-wars-how-israel-rethought-its-strategy-to-counter-iran (01.10.2019).

${ }^{74}$ R. Kopeć, P. Mazur, op. cit., s. 40.

75 A. Golov, op. cit., s. 86.

${ }^{76}$ Deterring Terror - How Israel ..., op. cit., s. 5.
} 


\section{Podsumowanie}

Strategia odstraszania Izraela zdecydowanie wyróżnia się na tle innych państw dysponujących bronią jądrową. Paradoksalna w kontekście klasycznych teorii odstraszania decyzja o utajnieniu własnego potencjału sprawia, że w przypadku Izraela to nie ilość, zasięg czy siła rażenia broni nuklearnej zniechęca potencjalnych agresorów. To właśnie domysły - często wyolbrzymione, nieoparte na potwierdzonych danych - wywołują niepokój i obawy innych aktorów na scenie międzynarodowej. Naturalna ludzka skłonność do strachu przed tym, co niepewne i nieznane, działa na korzyść Izraela. Niejawny charakter programu nuklearnego, uzupełniony uogólnionymi ,przeciekami” i sugestiami dyplomatów przekłada się na „strategię amimut", od lat znajdującą odbicie w działaniach władz Izraela i ich ambiwalentnym stosunku do międzynarodowego reżimu nieproliferacji. Paradoks izraelskiej strategii odstraszania nuklearnego objawia się też w innej płaszczyźnie: w tym przypadku to nie (domniemany) dysponent broni jądrowej podejmuje działania mające na celu uświadomienie przeciwnikom możliwości i gotowość do odwetu. Od lat 60. XX w. wszyscy przedstawiciele Izraela, niezależnie od proweniencji politycznej, uchylają się od jakichkolwiek jednoznacznych deklaracji, powtarzając ukute przez Leviego Eszkola stwierdzenie, że Izrael na pewno jako pierwszy nie wprowadzi broni jądrowej na Bliski Wschód. To przede wszystkim debata w innych państwach - zarówno wrogich Izraelowi, neutralnych, jak i sojuszniczych - buduje wizerunek Izraela jako posiadacza znacznego arsenału nuklearnego, który może zostać użyty, jeśli inne środki militarne zawiodą. Tym samym pierwszą z hipotez roboczych, zakładającą, że o potencjale odstraszania izraelskiego arsenału jądrowego decyduje celowe utrzymywanie go w sferze przypuszczeń, można uznać za pozytywnie zweryfikowaną.

Drugi element izraelskiej strategii odstraszania nuklearnego, nazywany „doktryną Begina”, odnosi się do obrony monopolu nuklearnego za wszelką cenę. Ta część strategii znalazła już dwukrotnie odbicie w praktyce. Badacze tematu pozostają dość zgodni co do aktualności tej doktryny - należy jednak podkreślić, że prawdopodobieństwo użycia głowic jądrowych do niszczenia celów w jakimkolwiek państwie, pretendującym do odebrania Izraelowi tego monopolu, jest nikłe. Dużo bardziej prawdopodobne jest wykorzystanie w tym celu środków konwencjonalnych. Z ,doktryny Begina” wynika także założenie o niemożności stworzenia na Bliskim Wschodzie równowagi potencjału nuklearnego, analogicznego do sytuacji między NATO a Układem Warszawskim w czasie zimnej wojny. Wiąże się to z kolei z uwarunkowaniami geograficznymi Izraela i ograniczoną zdolnością do przetrwania oraz wyprowadzenia kontrataku w przypadku uderzenia jądrowego.

Popularność teorii, mówiącej o istnieniu samobójczej „opcji Samsona”, z pewnością wzmacnia potencjał odstraszania Izraela, jednak tylko w ograniczonym zakresie. Odnosi się ona wyłącznie do sytuacji, w której Izrael nie miałby szans na obronę $\mathrm{i}$ w obliczu nieuchronnego unicestwienia własnej państwowości zdecydowałby się na środek ostateczny w postaci zmasowanego ataku jądrowego na centra dowodzenia i ludność przeciwnika, za 
cenę własnego zniszczenia. Być może strach przed takim rozwiązaniem działa odstraszająco na aktorów, których jedynym celem byłaby całkowita anihilacja Izraela i jego ludności, praktyka działania współczesnych przeciwników Izraela sugeruje jednak, że „opcja Samsona” nie zniechęca nikogo przed podejmowaniem działań zbrojnych na mniejsza skalę, które - mimo swej uciążliwości - nie zagrażają egzystencji państwa izraelskiego.

Broń nuklearna, choć w specyficznej formie, niewątpliwie odgrywa istotną rolę w strategii odstraszania Izraela. Trudno ze stuprocentową pewnością ocenić, jak duże jest jej znaczenie, ponieważ w żadnych jawnych dokumentach Izraelczycy nie odnoszą się do tego tematu. Bazując na ogólnych założeniach odstraszania, sformułowanych w najnowszej Strategii IDF, można jednak zauważyć, że część z nich musi opierać się na potencjale konwencjonalnym, gdyż wiąże się z odstraszaniem podmiotów nie stosujących się do przypisywanej państwom logiki i racjonalności - a ta stanowi warunek konieczny odstraszania nuklearnego.

Przedstawione w artykule rozważania pozwalają wysnuć wniosek, że izraelska broń jądrowa nie przedstawia większej wartości w kwestii odstraszania organizacji terrorystycznych i quasi-państwowych, których działalność stanowi obecnie najbardziej uciążliwe i kosztochłonne (niekoniecznie największe) zagrożenie dla bezpieczeństwa Izraela. Warto też podkreślić, że posiadanie przez Izrael broni nuklearnej nie powstrzymuje wrogo nastawionych państw przed wspieraniem wyżej wymienionych podmiotów ani przed realizacją własnych celów politycznowojskowych za ich pośrednictwem. Wiele wskazuje na to, że odstraszanie konwencjonalne Izraela jest obecnie dla jego przeciwników bardziej wiarygodne, niż groźba użycia broni jądrowej w odpowiedzi na agresję, która nie stanowi zagrożenia egzystencjalnego. Powyższe wnioski pozwalają stwierdzić, że druga przedstawiona we wstępie hipoteza (mówiąca o tym, że odstraszanie nuklearne stanowi część składową izraelskiej strategii odstraszania militarnego, jednak nie jest jej głównym elementem) również została w niniejszej pracy potwierdzona.

\section{BIBLIOGRAFIA}

AAP-6: Słownik terminów i definicji NATO. 2017. NATO Standardization Office.

Al Bu-Ainnain Khalid Abdullah. 2009. Proliferation assessment of ballistic missiles in the Middle East. Dubai: Institute of Near East and Gulf Military Analysis.

Aronson Shlomo. 1992. The politics and strategy of nuclear weapons in the Middle East. Opacity, theory and reality, 1960-1991: An Israeli perspective. New York: State University of New York Press.

Beaufre André. 1968. Wstęp do strategii. Odstraszanie i strategia. Warszawa: Wydawnictwo Ministerstwa Obrony Narodowej.

Beres Louis Rene, Shoval Zalman. 2019. Creating a Seamless Strategic Deterrent: an Israel Case Study W https://mwi.usma.edu/creating-seamless-strategic-deterrent-israel-case-study.

Brom Shlomo. 2005. Is the Begin Doctrine Still a Viable Option for Israel? W Getting Ready for a Nuclear-ready Iran, 133-158. Carlisle: Strategic Studies Institute, U.S. Army War College. 
Center for Strategic and International Studies. 2018.Israel's Ballistic and Cruise Missiles, W https://missilethreat.csis.org/country/israel.

Central Intelligence Agency. 1974. Special National Intelligence Estimate: Prospects for Further Proliferation of Nuclear WeaponsW https://nsarchive2.gwu.edu/NSAEBB/ NSAEBB240/snie.pdf.

Cohen Avner. 2010. The worst-kept secret: Israel's bargain with the bomb. New York: Columbia University Press.

Cohen Yoel. 2005. Whistleblowers and the Bomb: Vanunu, Israel and Nuclear Secrecy. London: Pluto Press.

Cozic Charles, Swisher Karin. 1992. Nuclear Proliferation: Opposing Viewpoints. New York: Greenhaven Press.

Delpech Therese. 2012. Nuclear Deterrence in the 21st Century. Lessons from Cold War for a New Era of Strategic Piracy. Santa Monica: RAND Corporation.

Belfer Center for Science and International Affairs. 2016.Deterring Terror - How Israel Confronts the Next Generation of Threats. English Translation of the Official Strategy of the Israel Defense Forces, Cambridge: Harvard Kennedy School.

Dowty Alan. 1978. "Nuclear Proliferation: The Israeli Case". International Studies Quarterly Vol. 22(1) : 79-120.

Eisenkot Gadi, Siboni Gabi. 2019. The Campaign Between Wars: How Israel Rethought Its Strategy to Counter Iran's Malign Regional Influence.W https://www.washington institute.org/policy-analysis/view/the-campaign-between-wars-how-israel-rethought-itsstrategy-to-counter-iran.

Evron Yair. 1994. Israel's nuclear dilemma. London: Routledge.

Farr Warner. 1999. The Third Temple's holy of holies: Israel's nuclear weapons. Maxwell: USAF Counterproliferation Center.

Feickert Andrew. 2005. Missile Survey: Ballistic and Cruise Missiles of Foreign Countries, Washington: Congressional Research Service.

Ford Peter. 2004. Israel's Attack on Osiraq: a Model for Future Preventive Strikes? Monterey: Naval Postgraduate School.

Giles Gregory. 2006. Continuity and Change in Israel's Strategic Culture. Washington: Defense Threat Reduction Agency.

Golov Avner. 2016. Israeli Deterrence in the 21st Century. Tel Aviv: Institute for National Security Studies.

Hersh Seymour. 1991. The Samson Option: Israel's Nuclear Arsenal and American Foreign Policy. New York: Random House.

International Atomic Energy Agency. 2019. List of Member States W https://www.iaea.org/ about/governance/list-of-member-states.

Israel Ministry of Foreign Affairs. 2011. Interview with PM Netanyahu on CNN-Piers Morgan Tonight Whttps://mfa.gov.il/MFA/PressRoom/2011/Pages/Interview _PM_Netanyahu_CNN_17-Mar-2011.aspx.

Israeli Ofer. 2015. „Israel's nuclear amimut policy and its consequences”. Israel Affairs Vol. 21(4) : 541-558.

Khan Saira. 2003. Nuclear Proliferation Dynamics in Protracted Conflict Regions. A Comparative Study of South Asia and the Middle East. London: Routledge. 
Kile Shannon, Kristensen Hans. 2018. World nuclear forces. W: SIPRI Yearbook 2018: Armaments, Disarmament and International Security, 235-302. Stockholm: SIPRI.

Kopeć Robert, Mazur Przemysław. 2017. Odstraszanie militarne w XXI wieku PolskaNATO - Rosja. Kraków: Uniwersytet Pedagogiczny im. KEN.

Krepnievich Andrew. 2013. Critical mass: Nuclear Proliferation in the Middle East. Washington: Center for Strategic and Budgetary Assessments.

Kristensen Hans, Norris Robert. 2014. „Israeli nuclear weapons, 2014”. Bulletin of the Atomic Scientists Vol. 70(6) : 97-115.

Lappin Yaakov. 2018. 'The War Between Wars': Israel vs. Iran in Syria W http://fathomjournal.org/the-war-between-wars-israel-vs-iran-in-syria.

Pedatzur Reuven. 2007. „The Iranian Nuclear Threat and the Israeli Options”. Contemporary Security Policy Vol. 28(3) : 513-541.

Raska Michael. 2011. „Beyond the "Bomb in the Basement”: Israel's Nuclear Predicament and Policy Options". Asian Journal of Public Affairs Vol. 1(2) : 22-33.

Riedel Bruce, Samore Gary. 2008. Report: Managing Nuclear Proliferation in the Middle East. Washington: Brookings Institution.

Sabel Robbie. 2018. „The Legality of an Attack against Iranian Nuclear Facilities”. INSS Insight No. 345.

Słownik terminów z zakresu bezpieczeństwa narodowego. 2008. Warszawa: Akademia Obrony Narodowej.

Spector Leonard. 1987. „Nuclear proliferation: who's next?”. Bulletin of the Atomic Scientists Vol. 4(7) : 17-20.

Steinberg Gerald. 2009. Iran in the Israeli Threat Perception. W The Iranian Puzzle Piece: Understanding Iran in the Global Context, 71:82. Quantico: Marine Corps University.

Szpyra Ryszard. 2012. Bezpieczeństwo militarne państwa. Warszawa: Akademia Obrony Narodowej.

Terill Andrew. 2009. „Deterrence in the Israeli-Iranian Strategic Standoff”. Parameters Vol. 39(1) : 81-94.

Yadlin Amos. 2018. „The Begin Doctrine: The Lessons of Osirak and Deir ez-Zor”.INSS Insight No. 1037.

Zych Joanna. 2017. „Wspólny Kompleksowy Plan Działania z 2015 r. w sprawie irańskiego programu nuklearnego - perspektywa Izraela”. Rocznik Bezpieczeństwa Międzynarodowego Vol. 11(1) : 131-147. 